\title{
Library and Information Service
}

\section{Recent donations}

We wish to thank the following authormembers who have generously donated copies of their work to the College Lbrary.

Dr J. L. J. Appleby, A Medical Tour Through the Whole Island of Great Brttain

Professor T. R. E. Barnes, Assessment Procedures for Psychoses

Dr J. Birtle, A Handbook for Personal Trainers

Professor S. Bloch, Foundations of Clinical Psychiatry

Dr N. Bouras, Mental Health in Mental Retardation

Professor J. L. Brooking. A Textbook of Psychiatric and Mental Health Nursing

Professor A. Burns, Dementia

Dr E. J. Byrne, Confustonal States in Older People

Dr S. P. Calloway, Russtan-Sovtet and Western Psychiatry

Professor G. N. Christodoulou, Topics in Preventtue Psychiatry

Dr J. Cutting. The Neuropsychology of Schtzophrenta

Dr J. C. Denmark, Deafness and Mental Health

Dr J. H. T. Ellard, The Anatomy of Mtracles
Dr M. Faulk, Basic Forensic Psychtatry 2nd Edition

Dr K. W. M. Fulford, Medicine and Moral Reasonting

Professor M. G. Gelder, Conclse Oxford Textbook of Psychitatry

Dr J. R. Gomez, Coptng with Thyrotd Problems

Dr R. D. Hinshelwood, Clinical Kletn

Professor S. C. Hollins, Hug Me, Touch Me

Dr R. Jenkins, Prevention of Suicide

Professor E. C. Johnstone, Searchtng for the Causes of Schtzophrenia

Professor C. L. E. Katona, Depression in Old Age

Dr P. J. McKenna, Schizophrenia and Related Syndromes

Professor H. Merskey, Classyfication of Chronic Pain 2nd ed.

Dr A. Obholzer, The Unconsclous at Work

Dr A. G. Patel, The Complete MRCPsych Part II

Dr M. Peet, Sexacal Pharmacology

Professor R. Srintvasa Murthy, Communtty Mental Health

Dr A. Stedeford, Facing Death: Patients, Families and Professionals 2nd ed.

Professor M. R. Trimble, New Anticonvulsants: Advances in the Treatment of Epllepsy

Professor G. Winokur, The Medical Basis of Psychiatry 2nd ed.

\section{College publications}

College publications can be purchased direct from the Royal College of Psychiatrists, 17 Belgrave Square, London SWIX 8PG. Telephone orders can be taken for payment by credit card (071 235 2351). Siu Lee, Book Sales Assistant, will be in the College on Monday morning and all day on Wednesday and Friday.

\section{Excerpta Medica}

We are pleased to announce that Psychiatric Bulletin is being covered by the Excerpta Medica database EMBASE from volume 19, 1995.

ALAN KERR, Editor 